\title{
A Study of EMP Curriculum Reform Based on the Need Analysis"
}

\author{
Yuan Kong \\ School of Foreign Languages, Jining Medical University, Jining, China
}

\begin{abstract}
ESP is a sort of English related to a particular profession or subject. ESP courses must be based on the analysis of the needs of the learners. The demand analysis in foreign language teaching is an empirical investigation and research, which is a dynamic diagnosis process for the implementation and improvement of teaching. The needs analysis before the beginning of the course can provide the basis for the setting of the curriculum, and make the curriculum more targeted. In the course of the needs analysis, the educators can adjust the teaching content and teaching methods according to the actual situation. After the needs analysis of the curriculum, teachers can help the teachers collect feedback information through comparative analysis to provide the basis for the follow-up curriculum reform.
\end{abstract}

Index Terms - EMP (English for medical purpose), demand analysis, curriculum reform

\section{INTRODUCTION}

In recent years, with the deepening of economic globalization and the enhancement of international exchanges, the demand for composite talents with solid professional knowledge and high English level has increased dramatically. This brings in new opportunities and challenges to college English teaching. Various types of colleges and universities have opened industry related ESP courses, such as business English, tourism English, medical English and so on. Based on this background, the author decided to investigate the needs of medical English Teaching in order to find out the problems existing in the course setting and teaching process of medical English. It is hoped that through the demand analysis, we will understand the actual requirement of their English ability in the teaching subject and the society, industry, starting from the actual needs of students and the society, and put forward the specific and feasible teaching reform scheme to help teachers more effectively implement the outline of teaching English courses, so as to change the present situation of medical English teaching, to provide help English courses for students learning and employment.

\section{DEMAND ANALYSIS}

In the 70s of last century, with the flourishing of ESP teaching research, demand analysis was introduced into language teaching. However, different scholars have different definitions of demand analysis.

Munby (1978) believes that demand analysis refers to the need for different learners to work through the adjustment of language courses. Yalden (1983) believes that demand analysis is the initial stage of language teaching, and it is the basis for determining teaching objectives, teaching content and teaching methods. Richards and Weber (1985) emphasize that demand analysis is a process to understand and determine language learners' needs and arrange their learning according to their importance. Hutchinson and Waters (1987) divide the requirements into target needs and learning requirements learning needs. Objective demand refers to knowledge and skills that learners must master in order to work smoothly in the future. They can be divided into knowledge, knowledge and knowledge. Learning needs refer to learners' knowledge, skills, strategies, motivations and learning conditions. Robinson (1991) thinks that needs analysis is to identify curriculum objectives by collecting and analyzing learners' objective needs, such as current learning level, learning difficulties. etc, and subjective needs (confidence and attitude towards language learning). Dudley-Evans \& St. John (1998) think that needs analysis is a continuous and dynamic process. Only through demand analysis can we determine course contents and teaching methods. Jarvis (1983) is more concise and points out: demand analysis is the need to investigate language learners.

In summary, the demand analysis is through various means such as questionnaires, tests, interviews and observation, find out the existing between the learner level and target level, so as to find the study origin and analyzing the problems generated and to determine the solution of a system of dynamic (Cai, 2012). Demand analysis is the starting point of ESP curriculum design. It is the foundation of ESP curriculum design, curriculum content, curriculum implementation

\footnotetext{
* Funding Sources: Social Science Planning Research Program of Shandong Province (Grant No. 17CWZJ38); Scientific Research Program of Colleges and Universities in Shandong Province (Grant No. J17RA054); Research Program of Young Teachers' Education and Teaching of Shandong Province (Grant No. 16SDJ232); Key Program in Art Science of Shandong Province (Grant No. ZX2015005); Youth and Adolescents Quality Education Work Planning Program of Shandong Province (Grant No. 13AJY090); Scientific Research Program of Jining Medical University (Grant No. JY2013RW032); The Visiting Scholar Funded Program of Young Backbone Teachers in Jining Medical University; College Students' Innovative Training Project of Jining Medical University (Grant No. cx2017052); Scientific Research Project of College Students in Jining Medical University (Grant No. JYXS2017RW017)
} 
and curriculum evaluation. It is also a prerequisite for ensuring the successful and effective completion of ESP teaching.

\section{DESIGN AND ImPLEMENTATION OF MEDiCAL ENGLish TEACHING REQUIREMENT}

\section{A. Research Problems}

The research problems in this paper are as follows:

(1) What are the students' needs and motives for medical English learning?

(2) Can the current medical English curriculum meet the students' actual learning and employment needs?

(3) Can the current classroom teaching model and the teaching material be used to arouse the students' interest in learning and promote the training of English ability?

(4) Whether English teachers meet the requirements of students' ideal medical English teachers, does the teaching evaluation system truly reflect the students' medical English ability?

\section{B. Research Objects}

The subjects of this study are divided into three categories

The first category is the 400 medical students randomly selected from the 2015 level students in a medical college. The students are covered with all the majors in the Department. They ended the semester's medical English learning, and had a more intuitive understanding of the medical English Teaching in the school, which could ensure the authenticity and reliability of the survey data.

The second category is the 20 full-time teachers who are engaged in English Teaching in the school. Among them, there are old teachers who have been teaching for nearly 30 years, and new teachers who have just graduated for two years, but at least have undertaken a round of medical English teaching. They have relatively rich teaching experience, which provide valuable suggestions for the smooth progress of the investigation.

The third category is 25 medical workers at all levels of medical units. They have a community hospital, a city level, a provincial two a, a three a hospital, which specializes in nursing, clinical, medical technology, pharmacy and so on. Through them, we mainly understand the importance and application of medical English in clinical work, and the specific needs of medical workers for medical English, so as to provide guidance for medical English teaching.

\section{Research Methods}

This study mainly adopts the method of combining theory with empirical research. First, the author reviewed the analysis related monographs of literature and the teaching of English for specific purposes and requirements, detailed study of Hutchinson \& Waters and Dudley-Evans' monographs on analysis of English for special purposes and requirements, on the basis of other scholars' research on preparation of medical English needs analysis questionnaire and interview outline, a comprehensive empirical study is undertaken by using the method of questionnaire investigation and interview.

1. Questionnaire survey

The questionnaire survey in this study is divided into two parts. The first part is mainly aimed at 400 students in 2015 medical school. The survey contents include students' background information, learning motivation and purpose, teaching material usage, teaching staff, teaching process, teaching evaluation system and teaching effect. The second part of the questionnaire mainly aimed at 25 medical workers at all levels of medical units. The contents of the survey included their background information, their needs for medical English, their most wanted medical English skills and suggestions for medical English teaching.

2. Interview

In order to further understand the needs of students, teachers and medical workers, and improve the needs survey, the author also made an outline for interviews with students, teachers and medical workers representatives, so as to get content information that could not be covered in the questionnaire. The student interviews were face-to-face interviews using the class and the spare time and students; the medical English teacher interviews are mainly face to face in the daily teaching work and weekly teaching activities after conversation; interview based on the medical workers by telephone interviews to complete individual doctors out time schedule accepted this interview.

\section{Collection of Data}

A total of 400 questionnaires and 25 medical workers were issued in this survey. In order to effectively retrieve the questionnaire, all the questionnaires were marked with numbers. Meanwhile, the questionnaire was also actively coordinated by the respondents, so the recovery rate of the questionnaire was $100 \%$. The author collates the questionnaire in time and inputs the data into the SPSS17.0 statistical software to convert the data into a chart so as to facilitate the subsequent comparative analysis. The interview was a semi - structured interview. With the consent of the interviewee, some interviews were recorded and the recordings were converted into word documents. All the interview records are summed up by the author himself.

\section{Analysis and Discussion on the InVEstigation Results of MEDiCAl EnGlish Teaching Demand}

Through the survey can be seen, all the English teachers surveyed, medical workers and most of the students think 
that English is very important in medical clinical practice, we should strengthen the medical English learning of medical students, offering medical English course is English Teaching in medical colleges and universities represent the general trend of reform (Feng, 2014). Moreover, most of the students are interested in and motivated by English learning. They hope to improve their English level and develop their comprehensive quality and enhance their employability through medical English course. Since the establishment of the medical English course, the Institute has achieved certain results, but there are also some obvious problems. The details are as follows:

\section{A. The Model of Medical English Curriculum Is Not Perfect}

The analysis shows that the medical English curriculum follows the following steps: Student needs analysis -teachers together discuss and confirm curriculum syllabus -- publishing curriculum materials with publishing houses -organization teaching, curriculum evaluation combined with formative and summative evaluation. The model consists of Hutchinson \& Waters (1987) put forward the five steps model is set in the curriculum, which needs analysis, syllabus design, teaching materials, teaching methods, curriculum evaluation, it is similar to the theoretical model of "Learning centered" curriculum set up by Hutchinson \& Waters, which is feasible in theory.

But according to the demand analysis mode, ESP needs analysis not only to concern learners' needs, but also to pay attention to learners' learning environment, that is, the needs of society (Dudley-Evans \& St. John, 1998). Only by combining learners' needs and social needs organically, can our medical English teaching be targeted and cultivate compound talents that are suitable for social development needs (Jiang, 2013). In the course of medical English courses, the medical colleges and universities only pay attention to the students' needs and lack the attention to the social needs. In addition, the mode setting ESP course Dudley-Evans \& St. John proposed is a dynamic process, needs analysis and curriculum evaluation of repeated courses related to constantly updated information, so to find the curriculum implementation problems in the process and make the corresponding adjustment (Lin, 2013). The medical English curriculum of the medical colleges and universities investigated is a fixed immutable and frozen mode, which has not been opened for any student needs survey, so teachers have to make appropriate adjustments in the process of teaching according to the curriculum evaluation results. But teachers are faced with different teaching groups every year, and the effect of this adjustment is not known.

\section{B. Medical English Courses Cannot Meet the Students' Need for English Practicality}

Although up to $82.1 \%$ of students, all teachers and medical workers think it is very necessary to set up a medical English course, but most of them think that the current medical English curriculum is not able to satisfy their practical needs of English. According to the survey, the link between the course and other professional courses is very high. Only $15.8 \%$ of college students, $70 \%$ of students indicate that two have a general connection, and $12.7 \%$ of students indicate that the relationship between the two is very small. In the survey of the total amount of medical English classes, $54.5 \%$ of the students think that the current class hours are too small and should be increased. In the interview, some students said that in addition to mastering some medical professional vocabulary and reading ability of medical English a little progress, other aspects of the gains were less.

In interviews with teachers, the teachers gave their own advice on when to open the course and the duration of the course. Some teachers believe that English learning should run through the students' college education. The first semester general English, help students through Grade Four examination; second semester basic medical English, medical English focuses on cultivating students' practical skills, to lay the foundation for medical English learning; third, fourth semester professional English test, such as English, English image, Pharmaceutical English, nursing English, students can more deeply learning and their own professional knowledge about English, so as to increase their employment competitiveness.

Richards and Weber (1985) emphasize that requirement analysis is a process to understand and determine language learners' needs and arrange their learning according to their importance. For now, it is necessary for the teaching management and execution department of the investigated institutions to conduct more extensive research on the society, market and students, so as to create effective medical English courses that can really meet students' needs.

\section{Medical English Teaching Methods and Means Are Obsolete and Single, and the Teaching Effect Is Poor}

Through the survey found that the teaching method is widely used in the current medical English class or the traditional grammar translation method, the teaching method of "Teacher centered", make the classroom become a teacher "teacher in Taiwan, What I say goes." impassioned on words, the translation text, students passively sitting there listening, taking notes the interaction between teachers and students, the lack of necessary, student interaction, make the classroom dull, unable to stimulate students' interest, but also defeated the enthusiasm of teachers (Qin \& Shi, 2014). The direct result of this teaching mode is that students have mastered many medical professional vocabularies and have improved their reading ability, but the comprehensive ability of language can't be exercised. Students' overall evaluation of medical English teaching is not high (Song, 2012).

In the questionnaire survey and interview, all the teachers and students said that multimedia has been widely used in the classroom teaching. But its main form is PPT courseware. Teachers only make slides for teaching contents, such as key words, medical terms, examples, etc., and present them to students in class. Although these courseware has changed the past "a book, a blackboard, a piece of chalk" teaching methods, to improve the efficiency of classroom teaching, and 
because they incorporate sound, pictures and other information, full of picture and sound, multi angle can mobilize students' emotion and attention, arouse students' interest and made some the teaching effect. However, there is no essential difference between the so-called multimedia teaching and the traditional teaching process (Wang, 2012). Because of selection, teaching strategies and methods from teaching content, the teaching steps to arrange the students in classroom activities, after-school practice teachers are pre- designed, students can only passively participate in the whole teaching process, not in accordance with their actual level and hobbies to choose to learn the content of their own level the activities and exercises are still being taught, and the modern multimedia teaching in the true sense there is still a gap. Of course, we say education is not fixed; medical English, as a new curriculum, is not a universal teaching method, teachers need to constantly sum up research in the practical teaching process, combining with the demand analysis, to find suitable for their students and effective teaching methods, so that students can benefit from learning in.

\section{The Teaching Content of Medical English Is Fixed and the Teaching Material Is Unchangeable}

The teaching material is the concrete embodiment of the syllabus and teaching content, and it is an important means to ensure the smooth implementation of the teaching. Hutchinson \& Waters (2002) suggests that the selection of medical English teaching materials should be in accordance with the following four criteria: (1) Authenticity, that is, the language material is the real material which is closely related to the future career of the students from the real context. (2) The appropriateness, that is, the selection of the textbooks must be difficult and moderate, which is in line with the level of the students. (3) Universality, that is, selected textbooks not only include language skills such as vocabulary, grammar and other language skills such as listening, speaking, reading and writing, but also include intercultural communication knowledge. (4) Compatibility, that is, the selected materials are closely related to the syllabus developed on the basis of demand analysis. The teaching materials used in this school are written on the basis of demand analysis and according to the syllabus. The survey data show that most students think the teaching material is moderate in difficulty. In the conversation with teachers, you also generally reflect that the textbooks currently used are not very difficult, and the structure is more reasonable, which involves all aspects of English teaching, such as listening, speaking, reading, writing and translation. But the students are not satisfied with the content of the textbooks used now. Only $29.1 \%$ of them are very interested or interested. Most of the students think that there is a large vocabulary in textbooks, and some of them are too long for reading articles. They lack the necessary listening and speaking training and are not practical enough. Such a result is not only a student's own problems, such as the weak foundation of students' English and the lack of interest in English learning, but also the reduction of their learning enthusiasm.

As everyone knows, the development of medical technology change rapidly, every day there will be the emergence of new diseases, there will be a new drug, there will be a new medical device in clinical use, but our textbooks since the publication of knowledge did not immutable and frozen, and update; teachers annually face different student groups, students English level, hobbies are different, training materials and teaching content is not conducive to the students personalized fixed. Therefore, appropriate additions and deletions to the teaching content and the revision of the teaching materials according to the students' actual conditions are an urgent problem to be solved.

\section{E. The Strength of Medical English Teachers Is Weak and the Structure of Teachers Needs to Be Improved}

Teachers are the key to the success or failure of teaching activities. The teaching of medical English has put forward higher requirements for teachers: teachers should not only have a solid foundation of English language, but also have certain medical professional knowledge. At present, the problem of teachers has become an important factor restricting the reform of medical English Teaching in the University, which is mainly shown in the following aspects: (1) The number of teachers is seriously inadequate and the teaching task of teachers is heavy. Due to the lack of teachers, English teaching has to be taught in large classes. (2) All the medical English teachers graduated from the English major, and none of them had the background of medical education. Although all teachers are aware of the importance of professional knowledge in medical English teaching, due to the heavy workload of teaching, there is no time and energy for medical English teaching research. (3) Medical English teachers lack the necessary approaches to further study and training. Since the course of medical English is opened, no teacher has been out to receive related training. In the actual teaching process, teachers encounter some medical problems that they don't understand. They can only consult other professional teachers, consult related professional books or seek help from the Internet. Everyone says the preparation is very stressful. At the same time, at the same time, in class, some professional knowledge do not dare to expand, worry about their mistakes and students questioned. Therefore, medical English classes are sometimes reduced to simple explanations of vocabulary, grammatical explanation and sentence translation. The survey shows that most students want medical English teachers to be a compound foreign language teacher with medical background. Obviously, the existing knowledge structure of medical English teachers and teachers has not been able to meet the needs of students. How to create conditions and improve the construction of teaching staff has become an urgent task for the school teaching management department.

\section{F. The Subject of Evaluation of Medical English Teaching Is Single, and the Way of Assessment Is Not Scientific}

In interviews, teachers generally reflected that the current evaluation of medical English teaching is mainly made by teachers, and the evaluation method is combined with formative assessment and summative evaluation. Formative assessment refers to the students' classroom attendance and homework, quizzes, summative assessment is the midterm 
and final exam, and then calculated according to a certain proportion of total. Due to the use of medical English teaching is the traditional grammar translation method, teaching contents to the vocabulary and grammar explanation and reading the texts translation, so the test for multiple choice, fill in the blanks, reading, translation, mainly from textbooks, compared with college English, only some technical appraisal. This kind of exam is to emphasize knowledge and students' memory test, so some students even if the class is not usually so serious, after no extra charge of self-study, only in a week or one or two days before the assault by staying up late can be mixed or high pass. Although the medical English class are listening and oral English teaching, but the evaluation system ignore the listening and speaking ability assessment, students' final grades do not reflect their true level of language, but also frustrated the learning enthusiasm of some students, contrary to medical English teaching, students can't meet the medical English learning needs.

\section{Countermeasures of Medical English Teaching Reform Based on Demand Analysis}

\section{A. To Carry out Comprehensive and Comprehensive Demand Analysis, Perfect the Curriculum and Optimize the Curriculum System}

1. To carries out comprehensive and objective needs analysis

According to the view of Hutchinson \& Waters (1987), demand is divided into objective demand and learning demand. Objective demand refers to knowledge and skills that learners must master in order to work smoothly in the future. Therefore, the author suggests that it is necessary to conduct a comprehensive investigation on the needs of a wide range of industries and medical workers, medical workers to understand the social requirements of language ability, the medical workers of my lack of knowledge in clinical work and they want to master the knowledge and skills, and find out from between the students' current level and industry demand gap for teachers to revise teaching materials, teaching plans, effectively implement teaching basis. In addition, our teachers annually face different teaching groups, the mental state of students, the level of knowledge, interest in learning different needs on the program will be different; at the same time the students' learning is a dynamic process, their learning needs is not the same $10 \%$.Therefore, we should run through the demand survey throughout the teaching process, not only before the course starts, but also in the curriculum, so that teachers can understand the needs of students in time and adjust accordingly. The investigation after the course is equally important, teachers through the analysis of survey results to identify problems, sum up experience, and the analysis results are applied to the curriculum design and teaching practice of the next round, in order to maximize meet the needs of the students, to achieve the goal of English Teaching in medicine.

2. To perfect the curriculum and optimize the curriculum system

Although the curriculum of medical English accords with the curriculum mode of ESP, but due to the lack of demand analysis, the current curriculum is no longer able to meet the actual needs of students, mainly due to the serious shortage of class hours and lack of occupational relevance. In view of this situation, the author puts forward two kinds of schemes. One is to open the course of College English and medical English at the same time without changing the total amount of English class. The course of College English elective courses and basic medical English courses the first semester, focus on the cultivation of students' practical skills of medical English, to lay the foundation for medical English learning; the second and third semester medical English test such as English, English image, Pharmaceutical English, nursing English, students can learn more deeply with their own professional knowledge about English. The two is to increase the total amount of English class hours, and make English study throughout the students' college education. Specifically for the first term to open College English, the second term to open the basic medical English, the third, fourth term to open professional English. But no matter which plan, it is imperative to set up medical English, and we must guarantee a certain amount of time. Only in this way can we meet the needs of industry and students (Zhang, 2013).

3. Clear goal of teaching

The goal of teaching is the starting point and final destination of all teaching activities (Zhao \& Wang, 2015). List of English Syllabus of medical English teaching goal: to consolidate and improve the students' basic knowledge of English language, listening, speaking, reading, writing and translation skills, learning about reading, translation skills, basic knowledge of medical English, improve the comprehensive ability of students in the actual work situation by using English in daily communication, and for the further study of professional English to lay the necessary foundation. It can be seen that the teaching goal of medical English in this hospital is concerned with the training of students' comprehensive ability, especially the skills of reading and translation (Wong \& Qi, 2013). This requirement is too general, and there is a certain gap between the findings of students and medical workers. The author proposes to further clarify the teaching objectives of medical English by combining the actual school and the results of the investigation of the students and medical workers: (1) students to expand their medical English vocabulary; (2) to strengthen the training of listening and speaking training in medical students, in the context of communicative competence; (3) to strengthen the medical students' English reading ability, can use English Dictionary access to professional literature; (4) to write simple medical application such as medical records, discharge summary, doctor proof. Besides, in the future, when offering professional English courses, we should make more detailed and definite teaching objectives according to the characteristics of different majors and the results of student needs analysis.

\section{B. To Speed up the Pace of Compilation and Revision of Teaching Materials and Enrich Teaching Content}


In the course of writing teaching materials, we are concerned only with the needs of the students, and do not include the needs of the industry. Therefore, before the revision of textbooks, we should conduct a comprehensive survey of needs of students and industries, understand the needs of industries and the changes of student needs, and cut and supplement teaching contents under the guidance of syllabus.

The development of medical technology is changing with each passing day. Teachers should follow the pace of the times, pay attention to the new trend of the development of the industry, update and supplement the teaching content in time. Teachers can select appropriate teaching contents according to the requirements of syllabus. At the same time, we should make full use of modern network technology, pass multimedia courseware, record micro lectures, and so on, and impart the contents that are not reflected in the textbooks to students.

\section{To Strengthen the Construction of Medical ESP Teachers}

On the one hand, a number of high quality medical English majors can be introduced directly. This can alleviate the number of medical English teacher shortage. At the same time, after several years of medical English learning, they not only lay a solid foundation for language, but also have certain medical knowledge, so they can go to teaching positions without special training. On the other hand, ESP experts and scholars can be regularly invited to the school to give lectures, and to guide the teaching theory and research methods of medical English teachers. Medical experts are regularly invited to teach English teachers, to impart basic medical knowledge and to promote the conversion of English teachers to compound English teachers.

The school may send willing to domestic and foreign English teachers in medical colleges and universities related majors such as inspection, image, pharmacy and other learning; It can also send a batch of foreign language foundation of good young professional teachers at home and abroad have set up medical English major college ESP teaching or teacher training base in practice learning, and give some incentives.

School establishment consists of English teachers and medical professional teachers of medical English teaching, teachers often organized collective classes, each course evaluation to improve the teaching level, mutual exchange of needed products, both inside and outside the school; Teachers attend to public courses, various levels of teaching competition, build learning platform for their exercise; It encourages teachers to carry out teaching study. English teachers can be combined with the professional teachers of various subjects reporting.

\section{Construction of "Flipped Class" Medical English Teaching Model Based on the Admiring Course}

The flipped classroom teaching mode can liberate teachers from the fetters of the tedious imparting knowledge, which is helpful for teachers to individualize teaching and train students' learning ability. The success or failure of flipped classroom depends on two links. One is "rollover", that is, teachers shoot and make birth teaching video, so that students can achieve information transmission before class. The two is "turning", that is, teachers can mobilize students' learning enthusiasm and achieve effective internalization of knowledge through a large number of interactive learning activities, such as group discussion, role play, situational simulation and keynote speech.

In the whole process, the student is the main body of the class, and the teacher is only the organizer and the instructor. Students solve problems of language and knowledge through class self-study and classroom answering questions, and participate in group discussions more actively and confidently. Meanwhile, network system evaluation, comprehensive evaluation of teacher evaluation and peer review can also urge students to learn initiatively. The flipping classroom teaching mode plays a great role in the cultivation of students' ability of thinking, innovation and self-learning.

\section{E. To Establish a Comprehensive Teaching Evaluation System Combining with the Profession}

\section{Phased test of students' English level}

We should have the first positioning test before starting the medical English course to understand students' current English level, and divide the class according to the results, in order to facilitate the teachers according to the syllabus of students' ability, teaching content and teaching methods; And then in achievement test in the course of the learning process, such as a chapter after the end of the unit test, or a learning stage after stage of the examination, to know whether students have mastered the solution outline specified language and skills, teachers can adjust the teaching, and make students aware of their weaknesses, clear effort direction. Competence test should always run through students' medical English learning. It encourages students to apply their language knowledge to practice and develop their comprehensive language use ability.

2. Examination content and form diversification

In order to achieve the goal of "Application - oriented" in medical English teaching, I think that the test of listening and oral English should be included in the examination scope. Although not all within the scope of the listening test in the midterm and final exam, but the teacher can carry on stage in the teaching process and the results recorded listening test; As for the oral test is more simple, daily oral English class communicative activities such as situational dialogue, group can be as oral ability evaluation the basis (Zhu, 2013). Teachers should inform students in advance, so that students can realize the importance of actively participate in classroom activities, and actively participate in classroom communication. In addition, after the end of the course, teachers can give specific scenarios according to the teaching module. Students are asked to combine the knowledge of the module and apply the medical communication language to simulate the situation, so as to test their comprehensive language application ability. 


\section{CONCLUSION}

Demand analysis is an important condition for the implementation of special purpose English teaching. First of all, effective demand analysis is of great significance for teachers to improve teaching methods and improve teaching effect. It can make teachers understand their own teaching objects and teaching goals clearly. They can make a definite target in the course of teaching and improve the efficiency and quality of teaching. Secondly, effective demand analysis can enable students to have a more comprehensive understanding of their learning situation, clarify their learning needs, and participate in the process of classroom teaching to a greater extent, thus increasing interest and enthusiasm in learning English. In this paper, through the investigation and analysis of demand for students, teachers, medical workers, the English curriculum, teaching mode, teaching materials, teachers and teaching evaluation are discussed, the abstract demand analysis theory into the curriculum and the actual teaching. Teaching can not only reduce the blindness and randomness, but also provides a realistic basis for medical English curriculum reform, and also provide a reference for the medical English Teaching in medical colleges.

\section{REFERENCES}

[1] Cai, J. G. (2012). "A Research on the ESP Curriculum Model of University Based on Demand Analysis." Foreign Language Teaching (3): 47-50.

[2] Cai, J. G. (2012). "The Demand Analysis of ESP under the Background of Internationalization of Higher Education." Computer-Assisted Foreign Language Education (9): 3-9.

[3] Dudley-Evans, T. \& St. John, M. (1998). Developments in English for Specific Purposes: Amulti-Disciplinary Approach. Cambridge: Cambridge University Press.

[4] Feng, Y. (2014). “Opportunities and Challenges of Foreign Language Curriculum in Colleges and Universities under the Background of Foreign Language Educational Technology.” Computer-Assisted Foreign Language Education (1): 78-79.

[5] Hutchinson, T. \& A. Waters. (1987). English for Specific Purposes: A Learning-Centered Approach. Cambridge: Cambridge University Press.

[6] Jarvis, J. (1983). “Two Core Skills for ESP Teachers”. The ESP Journal 2(1): 56-60.

[7] Jiang, L. P. (2013). "A New Teaching Mode of ESP -- Computer Assisted Translation Teaching." Education and Teaching Research (6):87-90.

[8] Lin, S. R. (2013). "Construction of English Skills Training Platform in Medical Colleges and Universities under the Dual Track of EGP and EOP.” Journal of Yangtze University (Natural Science Edition) (7):125-127.

[9] Liu, Y. (2012). "A Study of ESP Teaching Mode under the Perspective of Multimodal Discourse Theory." Journal of Chengdu Aeronautic Vocational and Technical College (6): 32-35.

[10] Munby, J. (1978). Communicative Syllabus Design. Cambridge: Cambridge University Press.

[11] Qin, Y. Z. \& L. Shi. (2014). “Application of Constructivism Learning Theory in Medical English Teaching.” Educational Exploration (3): 66-67.

[12] Richards, P. \& Weber. (1985). Longman Dictionary of Applied Linguistic: "A Technique for Measuring Reading Comprehension. London: Longman Publishing Group

[13] Song, F. (2012). "An Construction of a New Model of English Teaching in the ESP System of Nursing Industry." Journal of Suzhou University (1): 116-119.

[14] Wang, J. S. (2012). “An Application of Thematic Analysis in the Construction of ESP Textbooks -- Taking the Construction of Aerospace English Textbooks as an Example.” Journal of Northwestern Polytechnical University (6): 74-77.

[15] Wong, K. S. \& H. Qi. (2013). "An Research on ESP Teaching Based on Online Collaborative Inquiry Learning -- Taking WebQuest Based Medical English Teaching as an Example." E-education Research (1): 90-95.

[16] Yalden, J. (1983). The Communicative Syllabus: Evolution, Design and Implementation. Oxford: Pergamon.

[17] Zhang, Y. C. (2013). "Research and Thinking on the Construction of Micro-Class." China Education Network (10): 33-35.

[18] Zhao, K. \& Z. J. Wang. (2015). "Curriculum Design and Practice of College English Transformation in ESP." The theory and practice of foreign language teaching (2): 67-72.

[19] Zhu, Q. (2013). "An Analysis of Oral English Learners' Affective Factors Based on Needs Analysis.” Journal of Bohai University (3): 107-110.

Yuan Kong received her M.A. degree in linguistics. She is currently a lecturer at the School of Foreign Languages, Jining Medical University, Jining, Shandong, China. She teaches various subjects including: English intensive reading, English extensive reading, listening, nursing reading and so on. Her research interests mainly include English language teaching, applied linguistics, cross-cultural communication, etc. 